\title{
Natural durability of the culturally and historically important timber: Erythrophleum fordii wood against white-rot fungi
}

\author{
Thanh Duc Nguyen ${ }^{1}$ Hiroshi Nishimura ${ }^{1} \cdot$ Tomoya Imai $^{1} \cdot$ Takashi Watanabe $^{1} \cdot$ Yohsei Kohdzuma ${ }^{2}$. \\ Junji Sugiyama ${ }^{1,3}$ (i)
}

Received: 1 November 2017 / Accepted: 19 January 2018 / Published online: 17 February 2018

(c) The Japan Wood Research Society 2018

\begin{abstract}
The natural resistance of Erythrophleum fordii Oliver wood to degradation by Phanerochaete sordida and Phanerochaete chrysosporium white-rot fungi was investigated. In this study, Fagus crenata Blume (Japanese beech) was selected as reference species. The results showed that both fungi caused less than $2 \%$ mass loss in E. fordii wood, while the degradation of beech wood produced by $P$. chrysosporium and $P$. sordida was approximately 12 and $14 \%$, respectively. Microscopic observations revealed high structural rigidity of $E$. fordii timber. Hyphae were only observed in the lumen of vessels and parenchymal cells, while the fibers were not affected. The $E$. fordii wood fiber consisted of highly lignified thick-walled fibers with the fiber lumina almost completely closed. Two-dimensional heteronuclear single-quantum coherence nuclear magnetic resonance evaluation revealed the $E$. fordii wood to have a highly condensed-lignin structure that reflected by the durability classes. These unique parameters are likely to be critical for the high natural resistance of $E$. fordii.
\end{abstract}

Keywords Condensed lignin $\cdot$ Erythrophleum fordii Oliver · Fagus crenata Blume $\cdot$ Thicked-wall fibers $\cdot$ Wood decay

\section{Introduction}

Erythrophleum fordii Oliver is a precious hardwood tree species of Caesalpiniaceae and naturally distributed in Vietnam and South China. It is known by the name "Gemu" and is used by native Chinese people as an agent promoting invigoration and circulation [1, 2]. Moreover, Ganoderma lucidum (Curtis) P. Karst, which has high medicinal value, can be found in natural forests and plantations of this species when stumps decay. $E$. fordii has important medicinal value and toxic properties [3]. Alkaloids, triterpenoids,

Electronic supplementary material The online version of this article (https://doi.org/10.1007/s10086-018-1704-1) contains supplementary material, which is available to authorized users.

Junji Sugiyama

sugiyama@ rish.kyoto-u.ac.jp

1 Research Institute for Sustainable Humanosphere, Kyoto University, Uji, Kyoto 611-0011, Japan

2 Nara National Research Institute for Cultural Properties, Center for Archaeological Operation, 247-1 Saki-cho, Nara 630-8577, Japan

3 College of Materials Science and Engineering, Nanjing Forestry University, Nanjing 210037, China diterpenoids, and diterpenoid dimers have been isolated and identified from seeds, bark, and leaves [1, 2, 4-7]. The biological effects of alkaloids present in $E$. fordii have been reported [1, 5-7]. E. fordii also has important health and ecological benefits [8].

E. fordii is indeed a valuable timber tree species in tropical and subtropical regions with a clear distinction between heartwood and sapwood. The E. fordii tree produces quite hard, heavy, and durable wood, commonly called as 'iron wood', which is generally used for the production of ships, high-grade furniture, flooring, sculpture, and crafts $[9,10]$. Because of its superior wood, the E. fordii was classified in the most durable wood group in Vietnam [11]. It has been used as the traditional timber in many historical buildings in Vietnam.

Recently, wooden artifacts excavated from archaeological sites in Vietnam, such as Thang Long imperial citadel, Hanoi, Bach Dang stake yard, Quang Ninh, were identified as E. fordii. Interestingly, despite those artifacts being buried for hundreds of years, the degree of degradation of $E$. fordii wood was limited. The degradation of the wood's surface layer was limited to a depth of approximately $1-2 \mathrm{~cm}$. Below the outer surface layer, microscopic observation, chemical analyses, and mechanical tests revealed no significant differences between 
excavated and modern wood [12]. Considering the medicinal and antifungal properties of different parts of the plant, it is suggested that $E$. fordii wood would exhibit these properties. However, there are limited reports on natural durability of $E$. fordii wood.

Various organisms can induce wood to deteriorate, and the greatest level of deterioration is caused by fungi. White-rot fungi are among the most efficient degraders of plant fiber (lignocellulose), and are capable of degrading cellulose, hemicellulose, and lignin. They commonly cause rotten wood to feel moist, soft, spongy, or stringy, and to appear white or yellow [13-15]. Wood undergoes a number of changes during the decay process, including reductions in mass and strength [16-18]. Significant changes occur in the chemical composition of the cell wall during the fungal attack [16]. Attack of fungi causes a decrease in mechanical and physical properties of wood, influencing its moisture content, electrical conduction, acoustics, elasticity, and plasticity [19, 20].

The degradation of wood by white-rot fungi has been reported [21-23]. Different methods have been applied to investigate wood decay, including microscopy techniques [24-26]; differential scanning calorimetric [27]; X-ray diffraction [28]; gas chromatography — mass spectrometry (GC-MS) spectroscopy, chemical analysis [29, 30]; Nuclear magnetic resonance (NMR); and Fourier transform infrared spectroscopy [31-33]. Two-dimensional (2D) NMR techniques in the cell wall and lignin research have improved over the past decade [34]. Among various 2D NMR spectroscopic techniques available, Heteronuclear Single-Quantum Coherence (HSQC) is the most common. Solution-state 2D NMR provided an interpretable structural fingerprint of the lignin and carbohydrates of the cell wall, without further structural modification applied during the ball milling and ultra-sonication step [33, 35].

In this study, microscopic observations and chemical analyses were performed to illustrate the structural and chemical changes of the E. fordii wood degraded by white-rot fungi Phanerochaete chrysosporium Burdsall and Phanerochaete sordida (P. Karst.) J. Erikss. \& Ryvarden. The deterioration of $E$. fordii wood will be discussed and compared with Fagus crenata Blume (Japanese beech) wood. Investigation of natural resistance of $E$. fordii wood to wood decay fungi is essential for better understanding the characteristics of this wood, and for determining appropriate procedures to conserve archaeological waterlogged $E$. fordii wood.

\section{Materials and methods}

\section{Materials}

Samples of E. fordii and F. crenata Blume (Japanese beech) wood, $20 \times 20 \times 5 \mathrm{~mm}$ (tangential $\times$ radial $\times$ longitudinal dimensions), were cut from defect-free heartwood parts and used for further testing. The E. fordii wood was obtained from woods collection of Vietnamese Academy of Forest Sciences, Vietnam, while beech wood was received from Xylarium, RISH, Kyoto University, Japan.

Sulfuric acid was purchased from Wako Pure Chemical Industries, Ltd., Japan. Dimethyl sulfoxide- $d_{6}\left(\right.$ DMSO- $\left.d_{6}\right)$ was obtained from Sigma-Aldrich, USA.

\section{Wood decay testing}

Wood samples were exposed to two white-rot fungi $P$. sordida ATCC 90872 and P. chrysosporium ATCC 34541 for 4 weeks. The wood samples were oven-dried at $103{ }^{\circ} \mathrm{C}$ for $24 \mathrm{~h}$ and weighed prior to fungal exposure. The 3.8\% potato dextrose agar (PDA) aqueous solution was steamsterilized at $120{ }^{\circ} \mathrm{C}$ for $20 \mathrm{~min}$. In the next step, about $20 \mathrm{ml}$ of PDA medium was poured into a $90 \mathrm{~mm}$ Petri dish. Fungi were cultivated in Petri dishes on PDA medium. After inoculation, Petri dishes were held at $28{ }^{\circ} \mathrm{C}$ and $70 \%$ relative humidity to enable the fungi to spread over the entire dish. The specimens ( $n=3$ for each fungus) were steam-sterilized under the same conditions and then placed on the medium. After 4 weeks of incubation, the mycelia covering the blocks were removed carefully, and the blocks were oven-dried to constant mass. The mass loss $(W)$ of individual samples was calculated from the ovendried mass before and after fungal test, and used to calculate mean percentage of mass losses:

$\% W=\left[\left(W_{0}-W_{\mathrm{f}}\right) / W_{0}\right] \times 100$,

where $W_{0}$ is oven dry mass of sample prior to exposure and $W_{\mathrm{f}}$ is the oven dry mass following exposure to fungus.

\section{Light and scanning electron microscopy observation}

\section{Optical microscopy}

Small wood blocks, $2 \times 2 \times 2 \mathrm{~mm}$ (tangential $\times$ radial $\times$ longitudinal dimensions), were prepared from the nondegraded and biodegraded wood specimens. The specimens were dehydrated in a series of increasing concentration of acetone baths and embedded in Spurr resin [36]. The embedded specimens were cut at approximately $1 \mu \mathrm{m}$ thickness with a semi-thin microtome (Leica, Solms, Germany) equipped with a diamond knife. The sections were stained with toluidine blue for $3 \mathrm{~min}$ and then washed with distilled water for 1-3 min. The sections were observed using an optical microscope (BX51; Olympus, Tokyo, Japan) to investigate patterns of hyphal and decay of wood tissue. 


\section{Scanning electron microscopy observation}

The nondegraded and biodegraded specimens, $3 \times 3 \times 2 \mathrm{~mm}$ (tangential $\times$ radial $\times$ longitudinal dimensions), were prepared from internal part of samples. The clear wood surfaces were prepared using a microtome (TU-213, Yamato Scientific Co., Ltd., Japan). The specimens were freeze-dried for 2 days and then coated with platinum using an auto fine coater (JFC-1600, JEOL, Japan) operated at $30 \mathrm{~mA}$ for $90 \mathrm{~s}$. Field-emission scanning electron microscopy (SEM, JSM$7800 \mathrm{~F}$ prime, JEOL, Japan) was operated at an accelerating voltage of $1.5 \mathrm{kV}$.

\section{Chemical analysis}

\section{Lignin content}

Klason lignin content was determined in samples before fungal exposure. The nondegraded wood was powdered in a coffee grinder. The measurement was carried out on sieved material (in the range 60-100 mesh, corresponding to $0.15-0.25 \mathrm{~mm}$ ). The lignin content was determined in triplicate following the TAPPI method [37], which is based on the isolation of Klason lignin after the hydrolysis of the polysaccharides (cellulose and hemicellulose). The wood powder was immersed in concentrated sulfuric acid (72\%) for $4 \mathrm{~h}$. In the next step, the solution was transferred to an Erlenmeyer flask and diluted to $3 \%$ acid concentration with distilled water. These samples were boiled for $4 \mathrm{~h}$. The acid-insoluble lignin was then filtered off, oven-dried, and weighed.

\section{D HSQC NMR analysis}

To provide more detailed structural information, 2D HSQC NMR experiments were performed on nondegraded and degraded samples. The selected samples were grinded using laboratory-scale Mixer Mill MM301 (Retsch, Germany) for $5 \mathrm{~min}$. The extracted wood powder was finely ball-milled in a Mono Mill P-6 (Fritsch, Japan) centrifugal ball at $550 \mathrm{rpm}$ for $3 \mathrm{~h}$. Approximately $0.4 \mathrm{~g}$ of finely ball-milled wood powder was suspended in $2.8 \mathrm{ml}$ DMSO- $d_{6}$ in a plastic tube and sonicated in an ultrasonic cleaning bath for $30 \mathrm{~min}$. In the next step, the diluted solution was moved to an NMR tube. The 2D NMR spectra were recorded using a Bruker AVANCE III $600 \mathrm{MHz}$ UltraShield instrument (Bruker, Germany) operated at $600 \mathrm{MHz}$. Bruker pulse program hsqcedetgpsp. 3 was used for the HSQC experiments. The spectral widths were $16 \mathrm{ppm}(9615 \mathrm{~Hz})$ and $100 \mathrm{ppm}(15,091 \mathrm{~Hz})$ for the ${ }^{1} \mathrm{H}\left(\delta_{\mathrm{H}}\right)$ - and ${ }^{13} \mathrm{C}\left(\delta_{\mathrm{C}}\right)$-dimensions, respectively. The number of points (TD) was 2048 for the ${ }^{1} \mathrm{H}$-dimension with a recycle delay of $1.2 \mathrm{~s}$. The number of transients was 12 , and 256-time increments were recorded in the ${ }^{13} \mathrm{C}$-dimension. The optimum direct coupling $\left({ }^{1} J_{\mathrm{CH}}\right)$ used was $145 \mathrm{~Hz}$.

A semi-quantitative analysis of the integrals of the HSQC cross signal was conducted using Bruker Topspin 3.5 NMR software, and calculated based on the number of 100 aromatic units:

$\left(S+S^{\prime}\right) / 2+G+G^{\prime}=$ total integral of aromatics.

Relative integral value of the specific signal $\times$ per 100 aromatic units $=100 \times($ Integral-X $) /($ total integral of aromatics).

where $S$ is syringyl lignins; $G$ is guaiacyl lignins; $S, S^{\prime}$ is the integration of $S_{2,6}, S_{2,6}^{\prime}$, respectively. $G, G^{\prime}$ is the integration of $\mathrm{G}_{2}, \mathrm{G}_{2}^{\prime}$, respectively.

\section{Results and discussion}

\section{Mass losses}

All wood specimens were completely colonized by external mycelia after 4 weeks of incubation. The mean percentage mass losses of two wood species caused by different whiterot fungi are shown in Fig. 1. The mean mass loss of $E$. fordii wood caused by $P$. chrysosporium and $P$. sordida was only $2 \%$. However, these values for beech wood were 12 and $14 \%$, respectively. After exposure to these fungi, the tested samples were subjected to further microscopic observations and chemical analyses.

\section{Light and SEM microscopic observations}

Microscopic examinations of the woody biomass revealed different patterns of degradation between $E$. fordii wood and beech wood (Figs. 2, 3). A little degradation was observed in

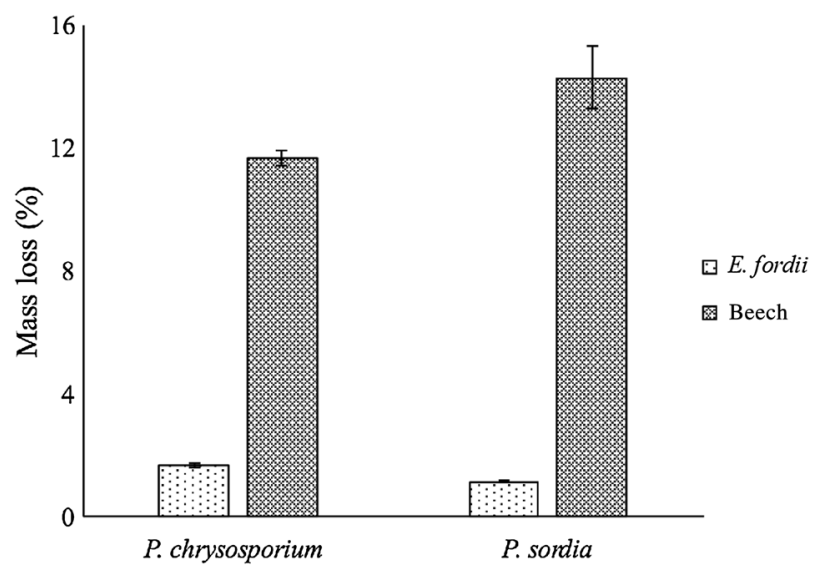

Fig. 1 Mean percentage mass loss in Erythrophleum fordii Oliver wood and beech wood after 4 weeks of exposure to two white-rot fungi. Error bars represent the standard error 
the vessel and parenchymal cells of E. fordii wood (Fig. 2a ${ }_{1}$, $\mathrm{a}_{2}$ ), while vessels and fiber cells of beech wood were deeply eroded by $P$. chrysosporium (Fig. $2 \mathrm{c}_{1}, \mathrm{c}_{2}$ ). P. sordida caused defibrillation through dissolution of the middle lamella in some parenchyma of $E$. fordii wood, while fiber areas were still intact (Fig. $2 b_{1}, b_{2}$ ). Besides, the defibrillation process occurred in several beech wood tissues (Fig. $2 \mathrm{~d}_{2}$ ). The
E. fordii wood had very thick-walled fibers with the fiber lumina almost completely closed (Fig. 2a $\mathrm{a}_{1}$ ). Because of the uniqueness of fiber structure, there was a little space for the development of hypha and hence limited the fungal degradation process.

During the decay process, changes in the structure of wood were hard to observe using light microscopy, while
Fig. 2 Cross sections of $E$. fordii wood and beech wood after 4-week exposure to whiterot fungi: $\mathbf{a}_{\mathbf{1}}-\mathbf{a}_{\mathbf{2}}$ E. fordii wood exposed to $P$. chrysosporium; $\mathbf{b}_{1}-\mathbf{b}_{2}$ E. fordii wood exposed to $P$. sordida; $\mathbf{c}_{\mathbf{1}}-\mathbf{c}_{\mathbf{2}}$ beech wood exposed to $P$. chrysosporium; $\mathbf{d}_{\mathbf{1}}-\mathbf{d}_{\mathbf{2}}$ beech wood exposed to $P$. sordida. Hyphal colonization in vessels lumina (v), axial parenchymas (p), and fibers (f) (arrows), especially vessels (arrow). Erosion and rupture in cell walls and defibrillation (arrowheads). $\mathbf{a}_{\mathbf{1}}, \mathbf{c}_{\mathbf{1}}$, and $\mathbf{d}_{\mathbf{1}}$ : bar $100 \mu \mathrm{m} ; \mathbf{b}_{1}$ : bar $50 \mu \mathrm{m} ; \mathbf{a}_{\mathbf{2}}, \mathbf{b}_{\mathbf{2}}$, $\mathbf{c}_{\mathbf{2}}, \mathbf{d}_{\mathbf{2}}$ : bar $20 \mu \mathrm{m}$
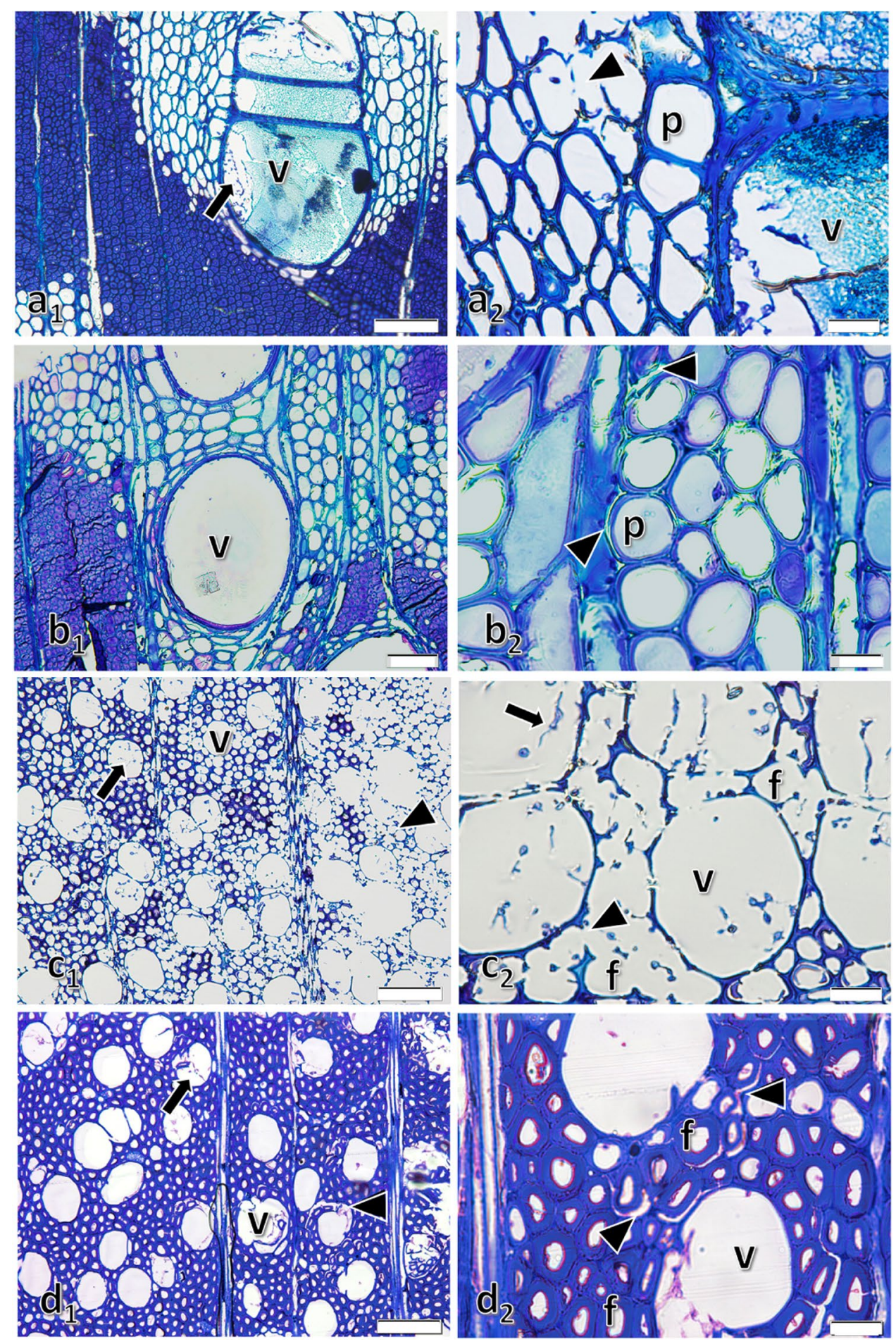

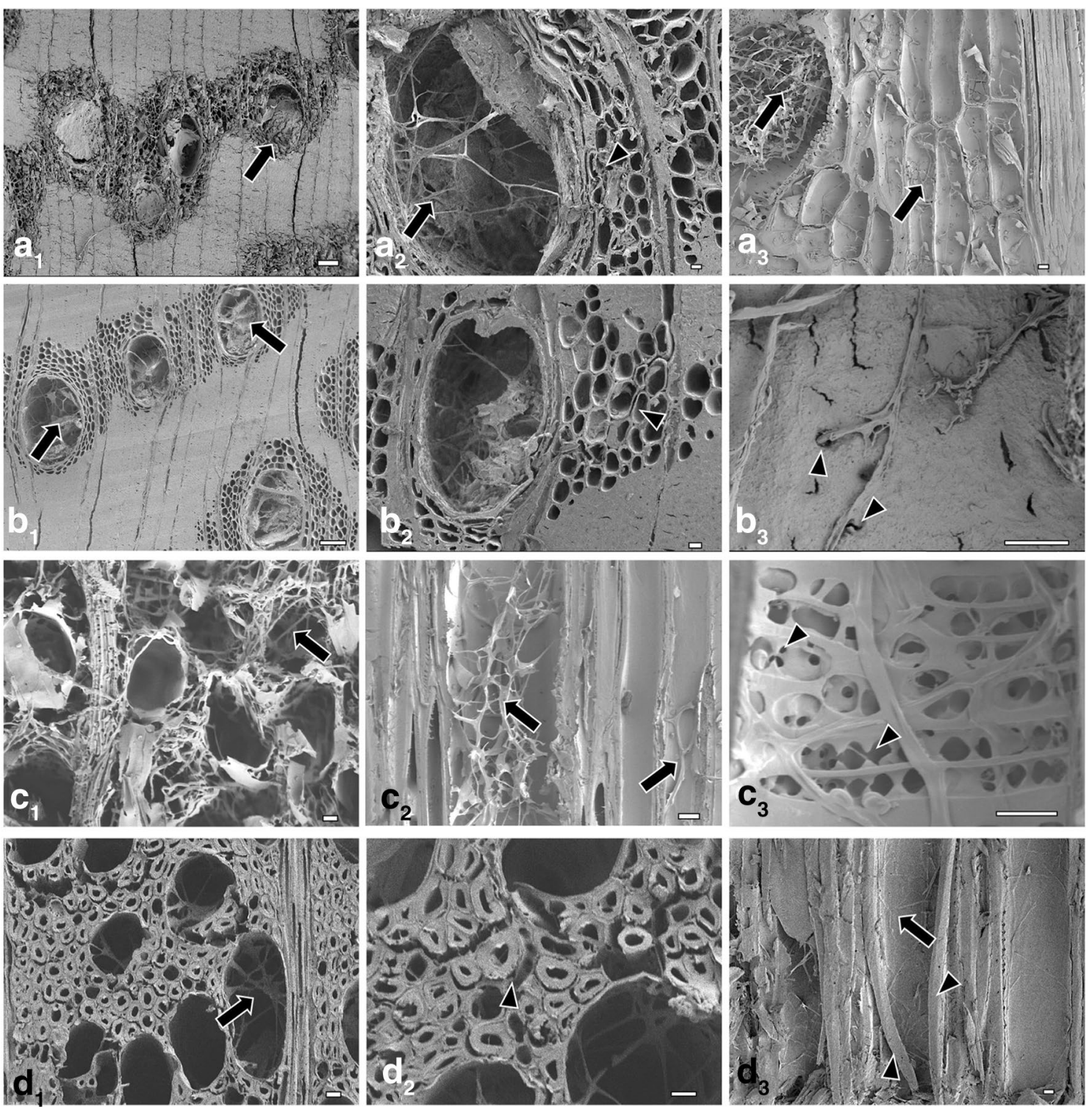

Fig. 3 Scanning electron micrographs of $E$. fordii and beech wood samples: $\left(\mathbf{a}_{1}-\mathbf{a}_{3}\right)$ E. fordii wood exposed to P. chrysosporium; $\mathbf{b}_{\mathbf{1}}-\mathbf{b}_{\mathbf{3}}$ $E$. fordii wood exposed to $P$. sordida; $\mathbf{c}_{\mathbf{1}}-\mathbf{c}_{3}$ beech wood exposed to $P$. chrysosporium; $\mathbf{d}_{\mathbf{1}}-\mathbf{d}_{\mathbf{3}}$ beech wood exposed to $P$. sordida; $\mathbf{a}_{1}-\mathbf{a}_{2}$, $b_{1}-b_{2}, c_{1}-c_{2}$ and $d_{1}-d_{2}$ cross sections: Colonization of hyphae in the lumen of vessels and fibers (arrows), deterioration of parenchyma ( $\mathbf{a}_{2}$

SEM clearly showed how the cell lumina were occupied by fungal hyphae. Hyphae were only observed in the lumen of vessels and parenchymal cells of $E$. fordii wood, while the fibers remained undamaged (Fig. $3 a_{1}, b_{1}$ ). Conversely, the hyphae were extended over whole tissues in beech wood (Fig. $3 \mathrm{c}_{1}, \mathrm{~d}_{1}$ ). The difference in decay mechanism of $P$. chrysosporium and $P$. sordida was obviously witnessed. The $P$. chrysosporium showed no selectivity to lignocellulose. The wood cell walls were eroded and the middle lamellae were degraded by activity of $P$. chrysosporium (Fig. $3 \mathrm{a}_{2}$, $\mathrm{c}_{1}$ ). This is different from $P$. sordida white-rot fungi which arrowhead), and defibrillation of wood tissue ( $\mathbf{b}_{2}, \mathbf{d}_{2}$ arrowheads). $\mathbf{a}_{3}, \mathbf{b}_{3}, \mathbf{c}_{\mathbf{2}}-\mathbf{c}_{3}$, and $\mathbf{d}_{\mathbf{3}}$ Radial sections: the presence of hyphae in the lumen of vessels and parenchymal cells $\left(\mathbf{a}_{3}\right)$ or vessels and fibers $\left(\mathbf{c}_{\mathbf{2}}\right)$; $\mathbf{b}_{\mathbf{3}}, \mathbf{c}_{\mathbf{3}}$ hyphae penetration in vessel pits and bore holes in vessel walls (arrowheads). $\mathbf{a}_{1}, \mathbf{b}_{\mathbf{1}}$ Bar $100 \mu \mathrm{m} ; \mathbf{a}_{2}-\mathbf{a}_{3}, \mathbf{b}_{\mathbf{2}}-\mathbf{b}_{3}, \mathbf{c}_{\mathbf{1}}-\mathbf{c}_{\mathbf{3}}$, and $\mathbf{d}_{\mathbf{1}}-\mathbf{d}_{\mathbf{3}}$ bar $10 \mu \mathrm{m}$

preferentially degraded lignin instead of polysaccharides, causing defibrillation of wood (Fig. $3 d_{1}-d_{3}$ ). These microscopic observations are consistent with previously reported [20, 38-40]. SEM observations revealed that fungi colonized its hyphae in vessel members and then penetrated the neighboring parenchyma cells of $E$. fordii (Fig. $3 \mathrm{a}_{3}$ ) or fiber cells of beech wood (Fig. $3 \mathrm{c}_{2}$ ) to promote degradation. Furthermore, observations in the radial direction showed the penetration of hyphae from vessel lumen into adjacent cells via vessel pits (Fig. $3 b_{3}$ ), and vessel-ray pits were destroyed by fungal activity (Fig. $3 \mathrm{c}_{3}$ ). This observation was supported 
by findings from the previous studies, which reported that hyphae tended to colonize the vessel lumen of infected hardwoods [41], then branch through simple or bordered pits to open pits, and resolve the hyphal penetration [16, 42].

\section{Chemical characterization}

Natural resistance to decay is one of the most important properties of wood, and is affected by the combination of wood density and the content and composition of lignin and extractives [43-45]. The antifungal test of E. fordii wood extractives was also performed. The results showed that $E$. fordii extractives were unable to inhibit the growth of fungi (see supplemental data). Therefore, the lignin structure is thought to be critical for resistance to degradation.

Lignin monomer composition and distribution among cell types and within different cell layers were the chemical parameters determining wood durability [46]. Based on TAPPI T222 om-98 examination, E. fordii wood had a higher Klason lignin content than beech wood. These values are $33.4 \%(0.14)$ and $20.6 \%(0.15)$ for E. fordii and beech wood, respectively. The numbers given in the brackets are standard deviation. Figure $4 \mathrm{a}-\mathrm{f}$ shows the 2D HSQC NMR spectra of the whole nondegraded and degraded woods obtained at the solution stage in DMSO- $d_{6}$. The main lignin substructures identified are also shown. The different lignin and polysaccharide cross signals assigned on the spectra are listed in Table 1, as previously described [23, 47, 48]. The results of a semi-quantitative analysis of the integrals of the HSQC cross signal are listed in Table 2. The differences between the spectra of fungal-degraded and nondegraded woods were observed. Cross peaks were observed at 106.2/6.47 $\left(\mathrm{G}_{\mathrm{c}}\right)$ and 107.4/6.26 $\left(\mathrm{G}_{\mathrm{c}}^{\prime}\right) \mathrm{ppm}$, which can be assigned to guaiacyl-condensed units. This is due to that correlation around $6.5 / 110 \mathrm{ppm}$ can be assigned to $\mathrm{C}_{6}-\mathrm{H}_{6}$ correlation of 4-O-5 structures based on the NMR data of lignin models, as previously reported [47]. However, the presence of the equivalent $\mathrm{G}$ units could not be unequivocally established. The most significant difference between lignin structures of $E$. fordii wood and beech wood was that the former had a new signal determined as $\mathrm{G}^{\prime \prime}{ }_{\mathrm{c}}$ (Table 2). Although this signal was slightly shifted to $108.5 / 6.90 \mathrm{ppm}$, it can be assigned to $\mathrm{C}_{2}-\mathrm{H}_{2}$ correlations on the aromatic rings of 4-O-5-linked unit [47, 48]. It is also indicated that the structure of condensed lignin contents a substituent in the $\mathrm{C}-5$ position, e.g., $5-5, \beta-5$, and $4-O-5$ structures [49]. The G/S-ratios of $E$. fordii were also higher than those of beech wood. Therefore, the main difference in the molecular structures of $E$. fordii and beech wood is the more condensed nature of $E$. fordii lignin. The localization and structure of lignin are important wood properties, because $\mathrm{G}$ are more strongly cross-linked, and therefore, more resistant to chemical degradation than lignin with a high S [43].
Analysis of the 2D HSQC NMR spectra of E. fordii wood (Fig. 4a-c) before and after fungal exposure revealed similar signals for lignin and polysaccharide moieties, including cellulose and hemicelluloses. The lignin intensities of degraded woods with their characteristic one-bond $\delta_{\mathrm{C}} / \delta_{\mathrm{H}}$ correlation at 108.5/6.90 $\left(\mathrm{G}^{\prime \prime}{ }_{\mathrm{c}}\right)$ were lower than those of nondegraded samples. On the other hand, the polysaccharide signals at 100.5/4.56 $\left(\mathrm{M}_{1}\right), 73.1 / 4.46\left(\mathrm{X}_{2}^{\prime}\right)$, and $74.8 / 4.80\left(\mathrm{X}_{3}^{\prime}\right)$ ppm of degraded and nondegraded samples were substantially less significant. Besides, these lignin and polysaccharide intensities of E. fordii wood exposed to $P$. chrysosporium were slightly lower than those of $P$. sordida.

In contrast to $E$. fordii wood, analysis of the 2D HSQC NMR spectrum of beech wood revealed a significant decrease in both lignin and polysaccharide signals (Fig. $4 \mathrm{~d}-\mathrm{f}$ ). The $\mathrm{C}_{2}-\mathrm{H}_{2}$ and $\mathrm{C}_{6}-\mathrm{H}_{6}$ in syringyl units were lower in treated woods because of fungal activity. The $\mathrm{C}_{\beta}-\mathrm{H}_{\beta}$ correlation in $\beta-O-4^{\prime}$ substructures $\left(\mathrm{A}_{\beta}\right)$ was observed at $\delta_{\mathrm{C}} / \delta_{\mathrm{H}} 83.5 / 4.30$ for $\beta-O-4^{\prime}$ substructures linked to $S$ units, at $\delta_{\mathrm{C}} / \delta_{\mathrm{H}} 86.3 / 4.04$ for $\beta-O-4^{\prime}$ substructures linked to $\mathrm{G}$ units, which decreased after the fungal test. Decreasing signals of other lignin substructures were also identified in the HSQC spectra. A strong signal for resinols $\left(\mathrm{B}_{\alpha}\right)$, phenylcoumaran $\left(\beta-5^{\prime}\right)$ substructures $\left(\mathrm{C}_{\alpha}\right)$, and spirodienone $\left(\mathrm{D}_{\alpha}\right)$ decreased in the wood treated with $P$. chrysosporium, while those values were relatively unchanged in the wood exposured to $P$. sordida. In addition to lignin removal, the NMR spectrum of the white-rotted wood also revealed a simultaneous increase in polysaccharide signal, especially for wood treated with $P$. chrysosporium. This may be because $P$. chrysosporium produced more extracellular slime called sheath, composed of $\beta$-glucan, in the sample analyzed and that the signal was observed at $\delta_{\mathrm{C}} / \delta_{\mathrm{H}} 103.1 / 4.30$ for $\beta$-D-glucopyranoside. While variations do exist concerning wood species, $P$. chrysosporium is well known to be a simultaneous white-rot fungus causing decay of lignin, cellulose, and hemicelluloses at the same rates. The $P$. sordida exhibited preferential delignification, as reported previously [20,46-48]. These findings are consistent with microscopic observation.

Wooden cultural properties are degraded by fungi (brownrot, white-rot, and soft-rot fungi) and bacteria (erosion, tunneling, cavitation, etc.). These processes, at the same time, are driven by different environmental factors which have not been explicitly explored within this study. Although further examinations are needed, the characteristic of a fungi-resistance E. fordii wood presented in this study is of particular relevance to the highly condensed lignin content as well as the compactness of wood fibers. This explains why E. fordii wood can survive underground for centuries, even for a millennium. The internal part of excavated $E$. fordii wood is sometimes intact and does not need to be preserved. In such cases, conservation of the degraded outer layer with 

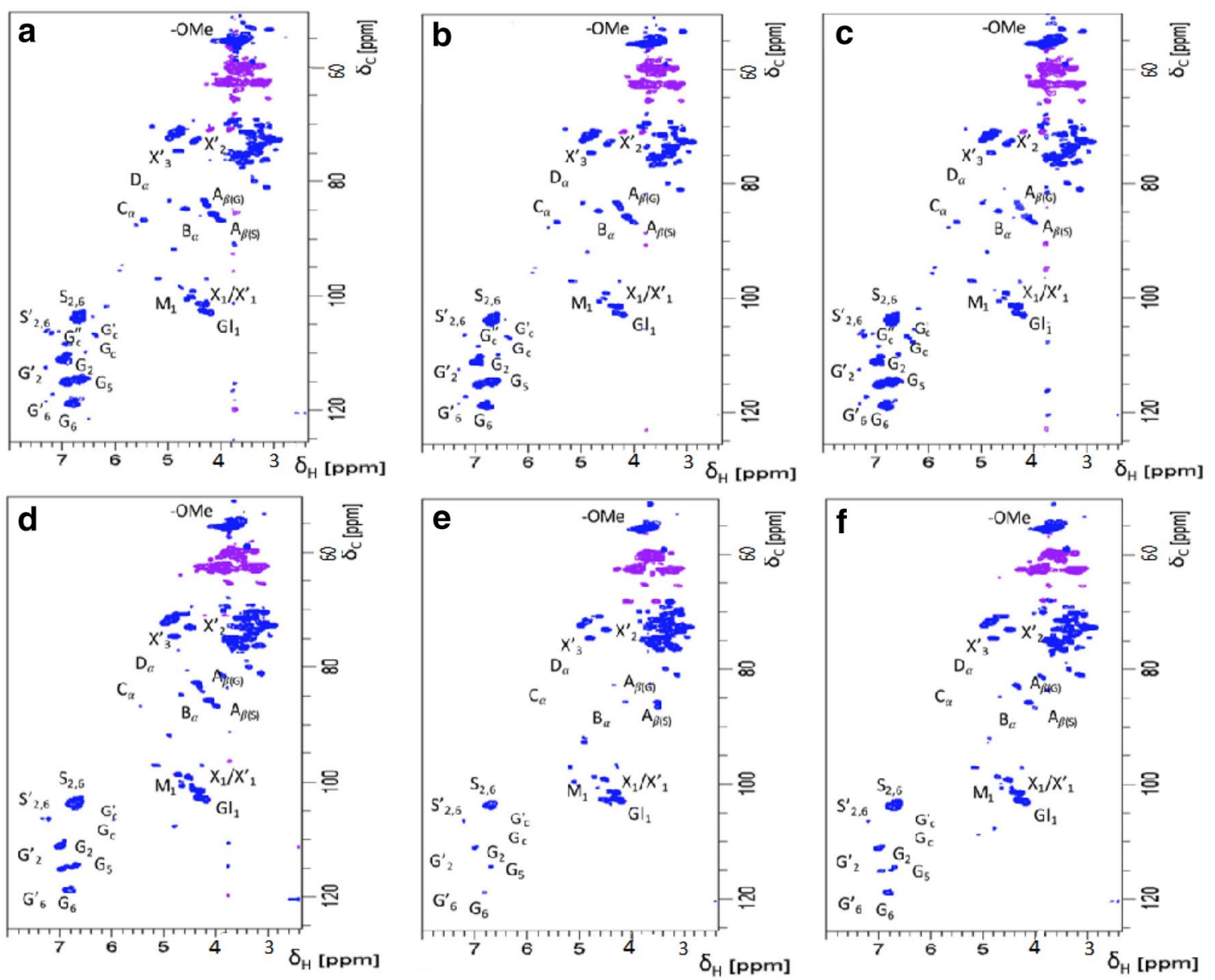

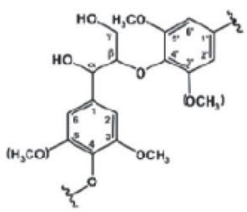

A<smiles>COCCOc1ccc(C(C)(C)C)cc1CC(C)(C)C</smiles><smiles>COc1cc(C(=O)O)ccc1Br</smiles>

$G^{\prime}$

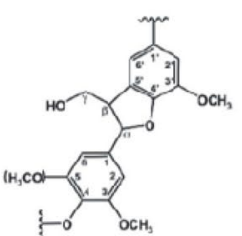

C

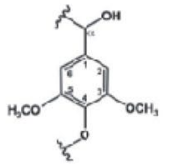

s

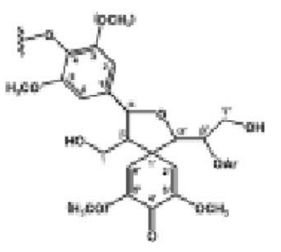

D<smiles>Cc1cc(C(=O)O)cc(O)c1Br</smiles>

$\mathbf{S}^{\prime}$
Fig. 4 2D HSQC NMR experiments in the solution state of: a nondegraded $E$. fordii wood; b $E$. fordii wood degraded by $P$. chrysosporium; and c E. fordii wood degraded by $P$. sordida; d nondegraded beech wood; e beech wood degraded by $P$. chrysosporium; and $\mathbf{f}$ beech wood degraded by $P$. sordida. The main lignin structures identified are also shown: A $\beta-O-4^{\prime}$ substructure; $\mathbf{B}$ resinol substructure; $\mathbf{C}$ phenylcoumaran substructure; $\mathbf{D}$ spirodienone substructure; $\mathbf{G}$ guaiacyl unit; G' $\mathbf{C} \alpha$-oxidized $\mathbf{G}$ unit; $\mathbf{S}$ syringyl unit; $\mathbf{S}^{\prime} \mathbf{C} \alpha$-oxidized $\mathbf{S}$ unit (R, lignin or $\mathrm{OH} ; \mathrm{R}^{\prime}, \mathrm{H}$ or lignin). See Table 1 for signal assignment 
Table 1 Assignment of lignin and polysaccharide ${ }^{1} \mathrm{H}-{ }^{13} \mathrm{C}$ correlation signals in the HSQC spectra shown in Fig. 4

\begin{tabular}{|c|c|c|}
\hline Labels & $\delta_{\mathrm{C}} / \delta_{\mathrm{H}}(\mathrm{ppm})$ & Assignment \\
\hline $\mathrm{S}_{2,6}$ & $103.9 / 6.69$ & $\mathrm{C}_{2}-\mathrm{H}_{2}$ and $\mathrm{C}_{6}-\mathrm{H}_{6}$ in syringyl units \\
\hline $\mathrm{S}_{2,6}^{\prime}$ & $106.4 / 7.18$ & $\mathrm{C}_{2}-\mathrm{H}_{2}$ and $\mathrm{C}_{6}-\mathrm{H}_{6}$ in $\mathrm{C}_{\alpha}$-oxidized syringyl units \\
\hline $\mathrm{G}_{\mathrm{c}}$ & $106.2 / 6.47$ & Condensed-lignin aromatics related to $4-O-5$ structures \\
\hline $\mathrm{G}_{\mathrm{c}}^{\prime}$ & $107.4 / 6.26$ & Condensed-lignin aromatics related to $4-O-5$ structures \\
\hline $\mathrm{G}_{2}$ & $111.3 / 6.95$ & $\mathrm{C}_{2}-\mathrm{H}_{2}$ in guaiacyl units \\
\hline $\mathrm{G}_{2}^{\prime}$ & $111.7 / 7.39$ & $\mathrm{C}_{2}-\mathrm{H}_{2}$ in $\mathrm{C}_{\alpha}$-oxidized guaiacyl units \\
\hline $\mathrm{G}_{6}$ & $118.9 / 6.75$ & $\mathrm{C}_{6}-\mathrm{H}_{6}$ in guaiacyl units \\
\hline $\mathrm{G}_{6}^{\prime}$ & $123.0 / 7.53$ & $\mathrm{C}_{6}-\mathrm{H}_{6}$ in $\mathrm{C}_{\alpha}$-oxidized guaiacyl units \\
\hline $\mathrm{G}^{\prime \prime}{ }_{\mathrm{c}}$ & $108.5 / 6.90$ & Condensed-lignin aromatics related to $4-O-5$ structures \\
\hline $\mathrm{A}_{\beta(\mathrm{G})}$ & $83.5 / 4.30$ & $\mathrm{C}_{\beta}-\mathrm{H}_{\beta}$ in $\beta-O-4^{\prime}$ substructures linked to a guaiacyl unit \\
\hline $\mathrm{A}_{\beta(\mathrm{S})}$ & $86.3 / 4.04$ & $\mathrm{C}_{\beta}-\mathrm{H}_{\beta}$ in $\beta-O-4^{\prime}$ substructures linked to a syringyl unit \\
\hline $\mathrm{C}_{\alpha}$ & $86.9 / 5.44$ & $\mathrm{C}_{\alpha}-\mathrm{H}_{\alpha}$ in $\beta-5^{\prime}$ (phenylcoumaran) substructures \\
\hline $\mathrm{B}_{\alpha}$ & $84.8 / 4.68$ & $\mathrm{C}_{\alpha}-\mathrm{H}_{\alpha}$ in $\beta-\beta^{\prime}$ (resinol) substructures \\
\hline $\mathrm{D}_{\alpha}$ & $81.3 / 5.08$ & $\mathrm{C}_{\alpha}-\mathrm{H}_{\alpha}$ in $\beta-1^{\prime}$ (spirodienone) substructures \\
\hline$-\mathrm{OMe}$ & $55.5 / 3.74$ & Methoxyl \\
\hline $\mathrm{Gl}_{1}$ & $103.1 / 4.30$ & $\mathrm{C}_{1}-\mathrm{H}_{1}$ in $(1-4) \beta$-D-glucopyranoside \\
\hline $\mathrm{X}_{1} / \mathrm{X}_{1}^{\prime}$ & $101.5 / 4.33$ & $\mathrm{C}_{1}-\mathrm{H}_{1}$ in $\beta$-D-xylopyranoside/3- $O$-acetyl- $\beta$-D-xylopyranoside \\
\hline $\mathrm{M}_{1}$ & $100.5 / 4.56$ & $\mathrm{C}_{1}-\mathrm{H}_{1}$ in $(1-4) \beta$-D-mannopyranoside \\
\hline $\mathrm{X}_{2}^{\prime}$ & $73.1 / 4.46$ & $\mathrm{C}_{2}-\mathrm{H}_{2}$ in $2-O$-acetyl- $\beta$-D-xylopyranoside \\
\hline $\mathrm{X}_{3}^{\prime}$ & $74.8 / 4.80$ & $\mathrm{C}_{3}-\mathrm{H}_{3}$ in $\beta$-D-xylopyranoside \\
\hline
\end{tabular}

Heteronuclear Single-Quantum Coherence

\begin{tabular}{|c|c|c|c|c|c|c|}
\hline \multirow[t]{2}{*}{ Labels } & \multicolumn{3}{|l|}{ E. fordii } & \multicolumn{3}{|l|}{ Beech } \\
\hline & Nondegraded & P. chrysosporium & P. sordida & Nondegraded & P. chrysosporium & P. sordida \\
\hline $\mathrm{S}_{2,6}$ & 77.0 & 81.4 & 81.9 & 103.9 & 84.9 & 103.1 \\
\hline $\mathrm{S}_{2,6}^{\prime}$ & 11.1 & 12.0 & 12.7 & 15.3 & 28.5 & 16.1 \\
\hline $\mathrm{S}_{\mathrm{c}}$ & 10.3 & 8.9 & 10.7 & 8.5 & 8.4 & 8.3 \\
\hline$S_{c}^{\prime}$ & 8.4 & 6.8 & 8.8 & 1.8 & 1.2 & 1.4 \\
\hline $\mathrm{G}_{2}$ & 47.1 & 44.8 & 44.3 & 33.1 & 31.1 & 32.6 \\
\hline $\mathrm{G}_{2}^{\prime}$ & 8.8 & 8.5 & 8.4 & 7.3 & 12.2 & 7.8 \\
\hline $\mathrm{G}_{6}$ & 52.9 & 48.8 & 54.4 & 32.3 & 31.6 & 32.9 \\
\hline $\mathrm{G}_{6}^{\prime}$ & 3.3 & 3.0 & 3.4 & 3.1 & 7.3 & 3.2 \\
\hline $\mathrm{G}^{\prime \prime}{ }_{\mathrm{c}}$ & 7.0 & 3.9 & 3.4 & 0.0 & 0.0 & 0.0 \\
\hline$A_{\beta(G)}$ & 21.8 & 22.2 & 19.2 & 27.9 & 18.8 & 26.2 \\
\hline $\mathrm{A}_{\beta(\mathrm{S})}$ & 30.2 & 33.0 & 30.6 & 29.7 & 16.4 & 27.6 \\
\hline $\mathrm{C}_{\alpha}$ & 5.5 & 5.6 & 5.7 & 3.8 & 2.5 & 3.5 \\
\hline $\mathrm{B}_{\alpha}$ & 9.5 & 10.8 & 10.6 & 7.1 & 5.7 & 7.4 \\
\hline$D_{\alpha}$ & 1.2 & 1.6 & 1.7 & 3.8 & 2.5 & 3.7 \\
\hline$-\mathrm{OMe}$ & 537.6 & 581.0 & 597.5 & 650.0 & 658.6 & 648.9 \\
\hline $\mathrm{Gl}_{1}$ & 25.9 & 28.2 & 29.6 & 65.3 & 187.3 & 78.8 \\
\hline $\mathrm{X}_{1} / \mathrm{X}_{1}^{\prime}$ & 48.5 & 49.5 & 49.1 & 64.5 & 78.8 & 73.5 \\
\hline $\mathrm{M}_{1}$ & 11.8 & 9.7 & 10.3 & 14.2 & 17.5 & 13.2 \\
\hline$X_{2}^{\prime}$ & 21.4 & 20.9 & 22.4 & 46.5 & 62.0 & 52.6 \\
\hline$X_{3}^{\prime}$ & 16.3 & 15.2 & 16.4 & 41.7 & 49.2 & 43.5 \\
\hline
\end{tabular}

Heteronuclear Single-Quantum Coherence 
an appropriate consolidation agent may be sufficient for this particular wood species.

Acknowledgements This study was partly supported by the Grantsin-Aid for Scientific Research (A) No. 25252033, Japan Society for the Promotion of Science, RISH Cooperative Research (database) and RISH Mission Research V, Kyoto University. The authors acknowledge the Xylarium, RISH, Kyoto University, Japan, and Vietnamese Academy of Forest Sciences, Hanoi, Vietnam for providing the wood materials.

\section{References}

1. Du D, Qu J, Wang JM, Yu SS, Chen XG, Xu S, Ma SG, Li Y, Ding GZ, Fang L (2010) Cytotoxic cassaine diterpenoid-diterpenoid amide dimers and diterpenoid amides from the leaves of Erythrophleum fordii. Phytochemistry 71:1749-1755

2. Nan LI, Fang YU, Shi-shan YU (2004) Triterpenoids from Erythrophleum fordii. Acta Bot Sin 46:371-374

3. Cheng JS, Zhen S (1987) Chinese virose plant. Science Press, Beijing

4. Ha MT, Tran MH, Phuong TT, Kim JA, Woo MH, Choi JS, Lee S, Lee JH, Lee HK, Min BS (2017) Cytotoxic and apoptosis-inducing activities against human lung cancer cell lines of cassaine diterpenoids from the bark of Erythrophleum fordii. Bioorganic Med Chem Lett 27:2946-2952

5. Hung TM, Cuong TD, Kim JA, Tae N, Lee JH, Min BS (2014) Cassaine diterpene alkaloids from Erythrophleum fordii and their anti-angiogenic effect. Bioorganic Med Chem Lett 24:168-172

6. Qu J, Hu YC, Yu SS, Chen XG, Li Y (2006) New cassaine diterpenoid amides with cytotoxic activities from the bark of Erythrophleum fordii. Planta Med 72:442-449

7. Tsao CC, Shen YC, Su CR, Li CY, Liou MJ, Dung NX, Wu TS (2008) New diterpenoids and the bioactivity of Erythrophleum fordii. Bioorganic Med Chem Lett 16:9867-9870

8. Zhigang Z, Junjie G, Er S, Jie Z, Jianmin X (2012) Natural distribution, endangered mechanism and conservation strategy of an endangered tree species, Erythrophleum fordii Oliv. In: Asia and the Pacific workshop-multinational and transboundary conservation of valuable and endangered forest tree species. IUFRO Headquarters, Vienna, pp 113-116

9. Chen T (1988) Flora of China. Science Press, Beijing

10. Fang XF, Fang BZ (2007) Wood physical and mechanical properties of Erythrophleum fordii in southern Fujian (In Chinese). J Fujian Forest Sci Technol 34:146-147

11. QD 2198-CN (1997) Classification of Vietnamese timber (in Vietnamese). Ministry of Agriculture and Rural Development, Vietnam

12. Bich DTN, Phuong LX, Nguyet NTM, Thu PTT, Nam NQ, Chuong PV (2011) Fundamental properties of some wooden objetcs excavated in Thang Long Imperial Citadel (in Vietnamese). Vietnam National University of Forestry, Vietnam

13. Mtui W, Nokes SE (2014) Lignocellulolytic enzymes from tropical fungi: Types, substrates and applications. Sci Res Essays 7(15):1544-1555

14. Mahajan S (2011) Characterization of the white-rot fungus Phanerochaete carnosa through proteomic methods and compositional analysis of decayed wood fibre. $\mathrm{PhD}$ thesis, University of Toronto, Canada

15. Jones D, Brischke C (2017) Performance of bio-based building materials. Woodhead Publishing Series in Civil and Structural Engineering. UK
16. Bari E, Nazarnezhad N, Kazemi SM, Ghanbary MAT, Mohebby B, Schmidt O, Clausen CA (2015) Comparison between degradation capabilities of the white rot fungi Pleurotus ostreatus and Trametes versicolor in beech wood. Int Biodeterior Biodegrad 104:231-237

17. Blanchette RA (1984) Screening wood decayed by white rot fungi for preferential lignin degradation. Appl Environ Microbiol 48:647-653

18. Blanchette RA (1984) Selective delignification of eastern hemlock by Ganoderma tsugae. Phytopathology 74:153-160

19. Cowling EB (1961) Comparative biochemistry of the decay of sweetgum sapwood by white-rot and brown-rot fungi. USDA Forest Service, Washington, DC

20. Schmidt O (2006) Wood and tree fungi: Biology, damage, protection, and use. Springer, Germany

21. Eriksson KEL, Blanchette RA, Ander P (1990) Microbial and enzymatic degradation of wood and wood components. Springer, Germany

22. Blanchette RA, Nilsson T, Daniel G, Abad A (1990) Biological degradation of wood. In: Rowell RM, Barbour RJ (eds) Archaeological Wood. Advances in Chemistry Series, No. 225. American Chemical Society, Washington, DC, pp 141-192

23. Martínez AT, Rencoret J, Nieto L, Jiménez-Barbero J, Gutiérrez A, Del Río JC (2011) Selective lignin and polysaccharide removal in natural fungal decay of wood as evidenced by in situ structural analyses. Environ Microbiol 13:96-107

24. Anagnost SE (1998) Light microscopic diagnosis of wood decay. IAWA J 19:141-167

25. Takano M, Hayashi N, Nakamura M, Yamaguchi M (2009) Extracellular peroxidase reaction at hyphal tips of white-rot fungus Phanerochaete crassa WD1694 and in fungal slime. J Wood Sci 55:302-307

26. Pelit H, Yalçın M (2017) Resistance of mechanically densified and thermally post-treated pine sapwood to wood decay fungi. J Wood Sci 63:514-522

27. Tsujiyama S (2001) Differential scanning calorimetric analysis of the lignin-carbohydrate complex degraded by wood-rotting fungi. J Wood Sci 47:497-501

28. Kim NH (2005) An investigation of mercerization in decayed oak wood by a white rot fungus (Lentinula edodes). J Wood Sci 51:290-294

29. Nishimura H, Sasaki M, Seike H, Nakamura M, Watanabe T (2012) Alkadienyl and alkenyl itaconic acids (ceriporic acids G and $\mathrm{H}$ ) from the selective white fungus Ceriporiopsis subvermispora: A new class of metabolites initiating ligninolytic lipid peroxidation. Org Biomol Chem 10:6432-6442

30. Zabell RA, Morrell JJ (1992) Wood microbiology, decay and its prevention. Academic Press, New York

31. Nishimura H, Yamaguchi D, Watanabe T (2017) Cerebrosides, extracellular glycolipids secreted by the selective lignin-degrading fungus Ceriporiopsis subvermispora. Chem Phys Lipids 203:1-11

32. Pandey KK, Pitman AJ (2003) FTIR studies of the changes in wood following decay by brown-rot and white-rot fungi. Int Biodeterior Biodegradation 52:151-160

33. Kim H, Ralph J, Akiyama T (2008) Solution-state 2D NMR of ball-milled plant cell wall gels in DMSO- $d_{6}$. Org Biomol Chem 1:56-66

34. Ralph J, Marita JM, Ralph SA, Hatfield RD, Lu F, Ede RM, Peng J, Quideau S, Helm RF, Grabber J, Kim H, Jimenez-Monteon G, Zhang Y, Jung HJG, Landucci L, MacKay J, Sederoff R, Chapple C, Boudet A (1999) Solution-state NMR of lignins. In: Argyropoulos DS (ed) Advances in lignocellulosics characterization. TAPPI Press, Atlanta, pp 55-108

35. Rencoret J, Marques G, Gutiérrez A, Nieto L, Santos JI, JiménezBarbero J, Martínez AT, Río JC (2009) HSQC-NMR analysis of lignin in woody (Eucalyptus globulus and Picea abies) and 
non-woody (Agave sisalana) ball-milled plant materials at the gel state. Holzforschung 63:691-698

36. Spurr AR (1969) A low-viscosity epoxy resin embedding medium for electron microscopy. J Ultrastruct Res 26:31-43

37. TAPPI T222 om-98 (1998) Standard methods for Acid-insoluble lignin in wood and pulp. TAPPI Press, Atlanta

38. Burdsall HH (1985) A contribution to the taxonomy of the genus Phanerochaete (Corticiaceae, Aphyllophorales). J. Cramer Publisher, Braunschweig

39. Koyani RD, Rajput KS (2014) Light microscopic analysis of Tectona grandis L.f. wood inoculated with Irpex lacteus and Phanerochaete chrysosporium. Eur J Wood Prod 72:157-164

40. Schwanninger M, Rodrigues JC, Pereira H, Hinterstoisser B (2004) Effects of short-time vibratory ball milling on the shape of FT-IR spectra of wood and cellulose. Vib Spectrosc 36:23-40

41. Wilcox WW (1970) Anatomical changes in wood cell walls attacked by fungi and bacteria. Bot Rev 36:1-28

42. Schwarze FWMR (2007) Wood decay under the microscope. Fungal Biol Rev 21:133-170

43. Nuopponen MH, Wikberg HI, Birch GM, Jääskeläinen AS, Maunu SL, Vuorinen T, Stewart D (2006) Characterization of 25 tropical hardwoods with Fourier transform infrared, ultraviolet resonance Raman, and ${ }^{13} \mathrm{C}$-NMR cross-polarization/magic-angle spinning spectroscopy. J App Pol Sci 102:810-819

44. Oliveira LS, Santana ALBD, Maranhão CA, Miranda RDCM, Lima VLAG, Silva SI, Nascimento MS, Bieber L (2010) Natural resistance of five woods to Phanerochaete chrysosporium degradation. Int Biodeterior Biodegrad 64:711-715

45. Onuorach EO (2000) The wood preservative potentials of heartwood extracts of Milicia excelsa and Erythrophleum suaveolens. Bioresour Technol 75:171-173

46. Skyba O, Douglas CJ, Mansfield SD (2013) Syringyl-rich lignin renders poplars more resistant to degradation by wood decay fungi. Appl Environ Microbiol 79(8):2560-2571

47. Li Y, Akiyama T, Yokoyama T, Matsumoto Y (2016) NMR assignment for diaryl ether structures (4-O-5 structures) in pine wood lignin. Biomacromol 17:1921-1929

48. Yue F, Lu F, Ralph S, Ralp J (2016) Identification of 4-O-5-Units in softwood lignins via definitive lignin models and NMR. Biomacromol 17:1909-1920

49. Heitner C, Dimmel D, Schmidt JA (2010) Lignin and lignans: advances in chemistry. CRC Press, London 